\title{
Species richness and biomass of understory vegetation in a Eucalyptus globulus Labill. coppice as affected by slash management
}

Received: 23 January 2006/ Accepted: 10 April 2006/Published online: 28 July 2006

(C) Springer-Verlag 2006

\begin{abstract}
The aim of this study was to assess the effect of different slash management practices on understory biodiversity and biomass in Eucalyptus globulus coppices in Central Portugal. The experiment consisted of four treatments: (a) removal of slash (R), (b) broadcast over the soil (S), (c) as in $\mathrm{S}$ but concentrating woody residues between tree rows (W) and (d) incorporation of slash into soil by harrowing (I). Understory vegetation was surveyed during $1-6,9$, and 10 years, the proportion of soil cover by plant species estimated, and diversity and equitability indexes determined. Above ground understory biomass was sampled in years $2-6,9$, and 10 . The highest number of species in most years occurred in plots where slash was removed. Differences between treatments in the proportion of plant soil cover were never significant, whereas differences in diversity index were only occasionally significant and apparently related to the number of species. Thus, differences in the equitability index were not significant. Understory biomass did not decrease during the rotation period, and was usually highest in R and I, and lowest in S, but not significantly different. At the end of the rotation period, understory biodiversity indices and biomass were apparently independent of slash treatment.
\end{abstract}

Keywords Biodiversity - Biomass - Eucalyptus coppice $\cdot$ Slash management $\cdot$ Species richness $\cdot$ Understory

Communicated by Franz Makeschin

M. Carneiro $(\bowtie) \cdot$ A. Fabião · M. C. Martins

C. Cerveira $\cdot$ C. Santos $\cdot$ C. Nogueira $\cdot$ M. Lousã $\cdot$ L. Hilário

A. Fabião $\cdot$ M. Abrantes · M. Madeira

Instituto Superior de Agronomia, Tapada da Ajuda,

1349-017 Lisbon, Portugal

E-mail: mcarneiro@isa.utl.pt

Tel.: + 351-21-3653365

Fax: + 351-21-3645000

\section{Introduction}

Short rotation plantations of Eucalyptus globulus Labill. have been expanding in Portugal during the last five decades. Intensive site preparation prior to stand establishment may cause significant impacts on soil properties (Alves 1988; Brosofske et al. 2001), reducing the amount of soil organic matter (Madeira et al. 1989), which may have a negative effect on the re-establishment of understory vegetation (Alves et al. 1990; Brosofske et al. 2001).

Harvesting is usually performed by clear cutting and frequently includes removal of slash, causing soil disturbance during timber extraction. Such practices adversely affect site fertility (Nyland et al. 1979; Abbott and Crossley Jr 1982; Burger and Prichett 1984; Smith et al. 1997), as well as the regeneration and survival of native species in the understory of forest plantations (Smith et al. 1997; Bauhus et al. 2001).

It is commonly thought that the management of eucalypt plantations negatively influences the biodiversity of understory vegetation (Rosa et al. 1986; Bernaldez et al. 1989; Bengtsson et al. 2000; Hartley 2002). However, some intensive forest plantations have surprisingly diverse understory (Keenan et al. 1997; Oberhauser 1997), and the planting of monocultures has even been recommended for restoring forest vegetation on degraded land, by providing a sheltered forest environment that allows colonisation of native species (Lugo 1997; Carnus et al. 2003).

Understory vegetation may play a particularly important role in the cycling and conservation of nutrients (Bauhus et al. 2001), protecting against soil erosion, and providing stability of soil aggregation (Tisdall and Oades 1982). Understory structure is an important determinant of ground-living fauna abundance as well as an important component of forest aesthetics (Bauhus et al. 2001). Moreover, understory vegetation is one of the most important elements of biodiversity within intensively managed forest 
plantations. It is an important indicator of overall biodiversity and ecological sustainability (Bengtsson et al. 2000), and often the best single predictor of faunal diversity (Humphrey et al. 1999) in such systems.

The management of harvest residues is becoming an increasingly important issue due to the potential effect of slash disposal on soil fertility and plant reproduction (Smith et al. 1997; Mendham et al. 2003). Therefore, the maintenance of slash after harvest may influence the development of understory plant species, depending on management alternatives. The need to ensure long-term biodiversity and sustainability of plantation forests argues for greater research effort in order to develop and implement design and management strategies that enhance plantation understory (Carnus et al. 2003).

The aim of this study was to evaluate the effect of alternative slash management techniques on biomass and species diversity of understory vegetation following coppice regeneration during the second rotation of 10 12 years in a plantation of E. globulus, which received intensive operations during establishment and later phases in Central Portugal. Preliminary results were published elsewhere in a different context (Fabião et al. 2002).

\section{Methods and materials}

\section{Site characteristics}

The experiment was established in March 1993 in a $E$. globulus plantation at Quinta do Furadouro $\left(39^{\circ} 20^{\prime} \mathrm{N}\right.$, $9^{\circ} 13^{\prime} \mathrm{W}, 30 \mathrm{~m}$ asl), in West Central Portugal, following coppicing of a previous first rotation eucalyptus plantation where tree density was approximately $1,111 \mathrm{ha}^{-1}$ $\left(3 \times 3 \mathrm{~m}^{2}\right.$ spacing $)$.

The site has a Mediterranean climate with an oceanic influence. Data from a meteorological survey station at Caldas da Raínha (approximately $12 \mathrm{~km}$ from the site, $70 \mathrm{~m}$ asl) shows that the mean annual temperature in the area is $15.2^{\circ} \mathrm{C}$, ranging from 10.4 in January to $19.8^{\circ} \mathrm{C}$ in August, with occasional occurrences of minimum temperatures below $0^{\circ} \mathrm{C}$ in winter. Mean annual rainfall is $607 \mathrm{~mm}$, with less than $10 \%$ occurring between May and September. High-atmospheric humidity values on summer mornings, as well as frequent summer fogs, reduce the effects of summer drought (Reis and Gonçalves 1981).

The soil at the experimental area is an Eutric Cambisol (FAO/UNESCO 1988), derived from Jurassic Sandstone with fossil remains of plants and dinosaurs (Zbyszewski and Almeida 1960). The principal soil characteristics are given in Fabião et al. (2002).

\section{Experimental design}

The experimental design consisted of four treatments: (R) removal of slash; (S) broadcast of slash over the soil surface; (W) as in (S), but concentrating the woody debris between tree rows; and (I) incorporation of slash into the soil by harrowing (approximately $20 \mathrm{~cm}$ depth). The experimental design was replicated in five different blocks. Each replicate was a plot of $30 \times 30 \mathrm{~m}^{2}$, with a core of 36 trees $\left(18 \times 18 \mathrm{~m}^{2}\right)$ surrounded by two buffer tree rows on the four sides. The sprouts were thinned ca. 3 years after clear-cut and left on the site in all treatments, a common practice in eucalyptus coppice management in Portugal.

\section{Floristic surveys}

The floristic surveys using the quadrat method (Kent and Coker 1992) were carried out every spring, during the first 6 years after coppicing. A $1 \times 1 \mathrm{~m}^{2}$ frame, subdivided into 100 squares, was randomly applied 4 times in each treatment plot. The line interception method (Kent and Coker 1992) was chosen in the ninth and tenth year, to avoid the risk of error that would occur when the quadrat method was applied in plots where understory woody plants had high dimension and/or density. A $15 \mathrm{~m}$ tape was used 4 times in each treatment plot. The proportion of surface cover of each species was estimated and recorded from the quadrat frame or the length intercepted along the measuring tape. Eucalyptus seedlings from natural seed reproduction as well as seedlings of other tree species were recorded as understory vegetation whenever found in samples.

\section{Assessment of understory biomass}

A wooden frame measuring $0.5 \times 0.5 \mathrm{~m}^{2}$ was randomly applied 4 times in each treatment plot every spring from 1995 to 1999 (second-sixth year), as well as in 2002 and 2003 (ninth-tenth year) for above ground biomass sampling. All the understory plants inside the frame were collected close to the ground and packed separately in identified plastic bags. They were immediately oven dried in the laboratory at $80-85^{\circ} \mathrm{C}$, for at least for $48 \mathrm{~h}$, and then weighed.

\section{Data handling and statistical analysis}

The data from floristic surveys were compiled and species lists by year and treatment plot were obtained. The proportion of soil cover of each species and bare soil in each treatment plot were averaged. The Shannon-Wiener diversity $(H)$ and equitability $(J)$ indexes (Begon et al. 1996) were calculated for each treatment plot using the proportion of soil cover by each species in relation to total plant cover and $e$-base logarithms. The oven-dry biomass of understory vegetation was organised in a similar way, integrated for each treatment plot and expressed on an area basis. 
The number of species, proportion of plant cover, diversity and equitability indices, and total understory biomass were statistically compared between treatments (SPSS for Windows, Version 11.5, SPSS Inc, Chicago, IL, USA). Normality of variance was confirmed by Kolmogorov-Smirnov test and the homogeneity verified by Levene test. Whenever the homogeneity was confirmed, the comparisons were performed through OneWay ANOVA procedure and Tukey test, where blocks and treatments were considered as independent variables and the estimated parameters as dependent variables. When homogeneity of variance was not confirmed, the averages were compared through the Dunnett's T3 test. The significance level of 0.05 was utilised in all the statistical analysis of data.

\section{Results and discussion}

\section{Number of species}

The mean total number of species per treatment plot was, in most years, highest in treatment $\mathrm{R}$ (slash removal) (Table 1), except in the third year when the highest number occurred in treatment I (incorporation of slash into the soil), although the value did not significantly differ from that in R. The lowest number of species occurred in treatment areas where slash was distributed on the soil surface, with statistically significant differences in relation to treatment $\mathrm{R}$ and/or I in the second, third, and ninth years.

Similar to the first 6 years of this study (Fabião et al. 2002), the negative influence of the presence of slash over the soil surface on the number of understory species surveyed was also confirmed at the end of the rotation. The results also suggest that variations in spring rainfall may contribute to temporal differences in the number of species present in the understory during the experimental period, since the highest scores occurred in the rainy

Table 1 Average number of understory species in various treatment plots

\begin{tabular}{lcccc}
\hline \multirow{2}{*}{ Years after coppicing } & \multicolumn{4}{l}{ Treatments } \\
\cline { 2 - 5 } & $\mathrm{R}$ & $\mathrm{S}$ & $\mathrm{W}$ & $\mathrm{I}$ \\
\hline 1 & 12.6 & 6.4 & 6.6 & 9.6 \\
2 & $8.0^{\mathrm{a}}$ & $4.6^{\mathrm{b}}$ & $5.6^{\mathrm{b}}$ & $5.4^{\mathrm{b}}$ \\
3 & $7^{\mathrm{a}}$ & $3.8^{\mathrm{b}}$ & $4.8^{\mathrm{a}, \mathrm{b}}$ & $8.2^{\mathrm{a}}$ \\
4 & 13.8 & 12.4 & 10.0 & 9.2 \\
5 & 14.6 & 11.2 & 12.4 & 11.6 \\
6 & 11.4 & 9.8 & 8.6 & 10.4 \\
9 & $11.0^{\mathrm{a}}$ & $10.6^{\mathrm{a}, \mathrm{b}}$ & $9.2^{\mathrm{a}, \mathrm{b}}$ & $7.6^{\mathrm{b}}$ \\
10 & 17.0 & 14.2 & 13.6 & 14.0 \\
\hline
\end{tabular}

The values followed by different characters in the same line were statistically different $(P<0.05$, ANOVA procedure and Tukey test). Treatments are: $R$ removal of slash, $S$ broadcast disposal of slash, $W$ as in $S$, but with woody slash concentrated between the tree rows, $I$ incorporation of slash into the soil by harrowing years (1997, 1998, and 2003) and the lowest in dry ones (1995, 1996, and 1999).

Three species tended to dominate the proportion of understory soil cover (not accounting for bare soil) in all the treatments during the study period (Fig. 1). The grass coloniser Holcus lanatus was the most frequent dominant species in all the treatments in the first 4 years of the rotation, with an exception in treatments $\mathrm{R}$ and $\mathrm{I}$ in the thirrd year, when Pteridium aquilinum was the dominant species. From the fourth year onwards, the presence of moss Funaria hygrometrica increased and become dominant in treatments $\mathrm{R}, \mathrm{S}$, and $\mathrm{W}$ in the fifth year and in $\mathrm{S}$ and $\mathrm{W}$ in the sixth year. P. aquilinum dominated the understory in treatment I cover from the fifth year until the end of the rotation. The importance of $P$. aquilinum in treatment I throughout the rotation (Fig. 1) indicates that the incorporation of slash into the soil by harrowing positively affected its survival and subsequent spreading, probably due to the fragmentation of the rhizomes.

Change in species composition appears to be related to the environmental changes at understory level following canopy closure after the fourth year, as discussed by Fabião et al. (2002). The relative importance of woody perennials strongly increased during the sixth year, as well as in the ninth- and tenth-year. Ulex europaeus (treatment $\mathrm{R})$, Quercus coccifera (R and W), Rubus ulmifolius (R, W and I), and Pinus radiata (S) are good examples of this tendency. However, at the end of the rotation, they were only dominant in treatment R, but still made a relevant contribution to soil cover in treatments $\mathrm{W}$ and I. In the treatment S, the only important woody perennials were the seedlings of $P$. radiata, due to natural regeneration from a nearby stand that was harvested during the experiment.

\section{Proportion of soil cover}

With the exception of the sixth year (when treatment I had the lowest value), treatment $\mathrm{S}$ (broadcast of slash over the soil surface) had the lowest proportion of soil cover by understory vegetation, although the differences between treatments were not statistically significant (Table 2). As previously observed (Fabião et al. 2002), treatment $\mathrm{R}$ usually had the highest proportion of understory vegetation cover in the experimental area. Exceptions occurred in the first- and fifth-year (with treatment I ranking the highest values), and in sixth- and tenth-year (treatment W). Differences to treatment $\mathrm{R}$ were negligible.

In our experiment, the canopy closure occurred in the fourth year, and was not significantly delayed by sprout thinning (Fabião et al. 2002). A decrease in understory plant cover should be expected after canopy closure (Spies 1997; Barnes et al. 1998; Brokaw and Lent 1999). However, almost all the treatments of the current experiment exhibited the highest understory plant cover proportion at the canopy closure stage (Table 2). 

covered by the three more abundant understory species in different treatments along the rotation period. Treatments are given in Table 1. HL Holcus lanatus, OP Ornithopus pinnatus, $R U$ Rubus ulmifolius, $L R$ Lepidophorum repandum, $C B$ Conyza bonariensis, $P A$ Pteridium aquilinum, $A C$ Agrostis curtisii, LP Lonicera periclymenum, EG Eucalyptus globulus, BS Brachypodium sylvaticum, ULE Ulex europaeus, FH Funaria coccifera, PR Pinus radiata
Fig. 1 Proportion of soil hygrometrica, QC Quercus
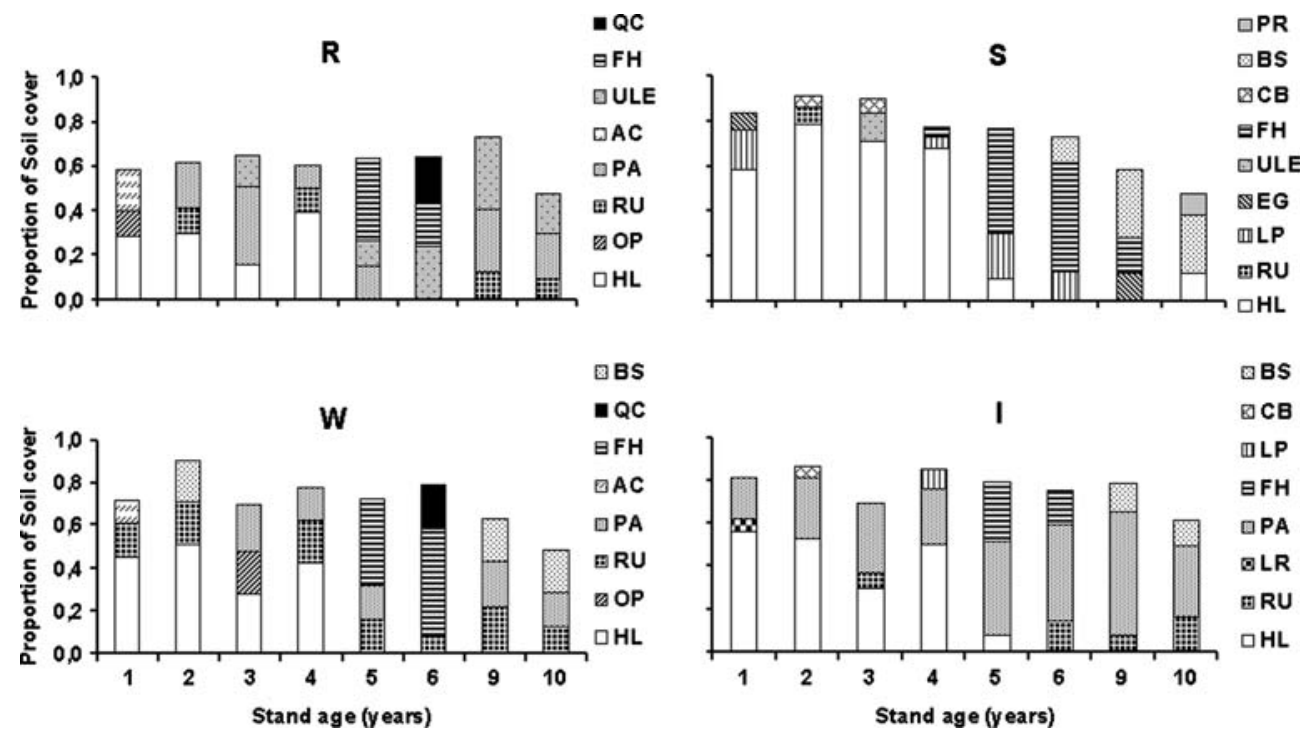

Table 2 Average proportion ( $\%$ of total area, including uncovered soil) of understory plant cover in treatment plots

\begin{tabular}{lllll}
\hline Years after coppicing & \multicolumn{4}{l}{ Treatments } \\
\cline { 2 - 5 } & $\mathrm{R}$ & $\mathrm{S}$ & $\mathrm{W}$ & $\mathrm{I}$ \\
\hline 1 & 52.7 & 26.4 & 42.5 & 54.1 \\
2 & 51.7 & 32.7 & 51.5 & 43.7 \\
3 & 56.8 & 20.2 & 55.9 & 49.1 \\
4 & 91.2 & 77.8 & 88.2 & 80.4 \\
5 & 60.3 & 41.4 & 62.1 & 65.1 \\
6 & 58.7 & 58.0 & 66.7 & 40.1 \\
9 & 53.2 & 19.1 & 43.8 & 36.2 \\
10 & 81.1 & 55.1 & 85.5 & 73.6 \\
\hline
\end{tabular}

The differences between treatments were not statistically significant $(P>0.05$, ANOVA procedure). Treatments are given in Table 1

Thomas et al. (1999) also observed that the understory cover values of a Pseudotsuga menziesii plantation in Western Washington State (USA) increased with thinning treatments. These findings may be due to the increased dominance by one or few of the understory species, especially small ferns and grasses. In our experiment, an increase in the proportion of plant cover in the fourth year may have resulted from either higher than normal levels of spring rainfall or the high contribution of $F$. hygrometrica and $P$. aquilinum to understory cover following sprout thinning.

\section{Shannon-Wiener diversity and equitability indexes}

The effect of treatments on Shannon-Wiener diversity index was not clear (Table 3). Significant differences between treatments only occurred in the third year between treatments $\mathrm{S}$ and I. Treatment $\mathrm{R}$ usually ranked the highest diversity index in the first 6 years, with exception of the third and sixth years, when treatment I had the highest values. In the ninth- and tenth-year, treatments $\mathrm{W}$ and $\mathrm{S}$ (consisting in broadcast of slash over the soil surface), respectively, scored the highest indexes. The lowest value for diversity was in treatment I in the first-, second-, fourth-, ninth-, and tenth-year, in treatment $\mathrm{S}$ in the third-year, and in treatment $\mathrm{W}$ in the fifth- and sixth-year.

Most of the differences between treatments in the diversity index are related to differences in the average number of species in each treatment and year, confirmed by the absence of significant differences in the equitability index between treatments (Table 4). The highest equitability index values were observed in treatment $\mathrm{R}$ in the first-, second- and fourth-year, but in other years the maximum value was shared between treatments I (thirdand fifth-year), S (sixth- and tenth-year), and W (ninthyear).

Moore and Allen (1999) stated that in intensively managed forest plantations, clear-cut harvesting promotes a more diverse flora than under an undisturbed canopy. This is due to increases in solar radiation and temperature following complete canopy removal, which promotes higher rates of photosynthesis and nutrient

Table 3 Shannon-Wiener diversity index in treatment plots

\begin{tabular}{lllll}
\hline Years after coppicing & \multicolumn{5}{l}{ Treatments } \\
\cline { 2 - 5 } & $\mathrm{R}$ & $\mathrm{S}$ & $\mathrm{W}$ & $\mathrm{I}$ \\
\hline 1 & 1.549 & 1.092 & 1.119 & 1.082 \\
2 & 1.171 & 0.745 & 0.900 & 0.740 \\
3 & $1.054^{\mathrm{a}, \mathrm{b}}$ & $0.627^{\mathrm{a}}$ & $0.804^{\mathrm{a}, \mathrm{b}}$ & $1.287^{\mathrm{b}}$ \\
4 & 1.357 & 1.112 & 1.018 & 0.941 \\
5 & 1.531 & 1.355 & 1.241 & 1.361 \\
6 & 1.321 & 1.350 & 0.933 & 1.352 \\
9 & 1.441 & 1.695 & 1.714 & 1.052 \\
10 & 1.699 & 1.845 & 1.761 & 1.488 \\
\hline
\end{tabular}

The values followed by different characters in the same line were statistically different $(P<0.05$, ANOVA procedure and Tukey test). Treatments are given in Table 1 
Table 4 Shannon-Wiener equitability index in treatment plots

\begin{tabular}{lllll}
\hline Years after coppicing & \multicolumn{4}{l}{ Treatments } \\
\cline { 2 - 5 } & $\mathrm{R}$ & $\mathrm{S}$ & $\mathrm{W}$ & $\mathrm{I}$ \\
\hline 1 & 0.617 & 0.588 & 0.611 & 0.490 \\
2 & 0.578 & 0.486 & 0.560 & 0.433 \\
3 & 0.533 & 0.471 & 0.542 & 0.622 \\
4 & 0.438 & 0.416 & 0.361 & 0.335 \\
5 & 0.570 & 0.569 & 0.497 & 0.597 \\
6 & 0.546 & 0.588 & 0.438 & 0.578 \\
9 & 0.591 & 0.720 & 0.758 & 0.524 \\
10 & 0.598 & 0.696 & 0.682 & 0.558 \\
\hline
\end{tabular}

The differences between treatments were not statistically significant $(P>0.05$, ANOVA procedure). Treatments are given in Table 1

mineralisation at understory level. Site managementafter harvest and during the first half of the rotation is of major importance to both timber production and biodiversity (Bailey and Tappeiner 1998). Although some kind of temporal trend in diversity of understory vegetation was expected in the current experiment, results suggest that stand age and differences in environmental characteristics, such as variation in the amount of spring rainfall, had greater influence on diversity than treatments.

\section{Biomass}

The biomass of understory vegetation did not decrease along the rotation, and was usually highest in treatments $\mathrm{R}$ or I (the latter in the second- and fifth-year), and consistently lowest in treatment $\mathrm{S}$, although differences were not significant (Fig. 2). The aforementioned major contribution of $F$. hygrometrica to the proportion of understory plant cover in the fourth year did not correspond to a parallel increase in biomass due to the small stature of this species. The increase of understory biomass in all the treatments during the tenth year of the experiment may be related to a high amount of spring rainfall that year.

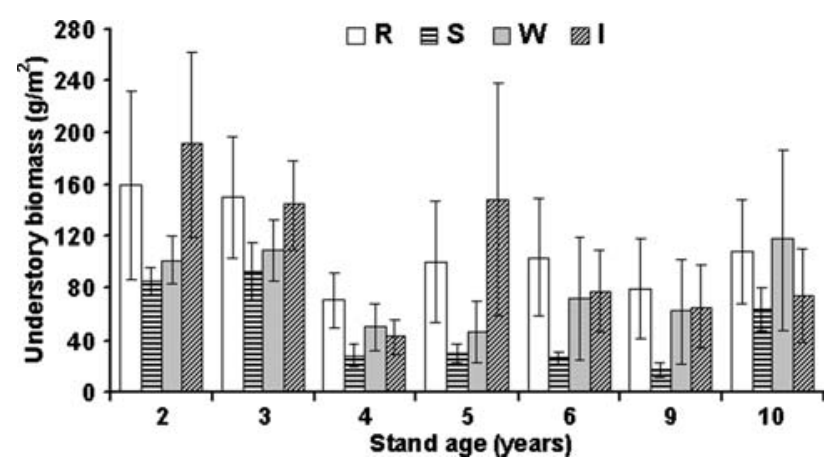

Fig. 2 Variation of the understory biomass along the rotation. The vertical bars represent \pm 1 standard error. The differences between treatments were not statistically significant $(P>0.05$, ANOVA procedure). Treatments are given in Table 1
Biomass values measured after 10 years of stand development suggest that spreading slash over the soil surface inhibits understory vegetation development. This finding is supported by the observation of the lowest number of species during the first 3 years of the rotation and the lowest proportion of soil cover during most of the experimental period in treatment S. Inhibition and subsequent development of understory vegetation might have been caused not only by soil shading by slash disposal (Fabião et al. 2002), but also competition for nitrogen between understory vegetation and decomposing woody debris.

\section{Conclusions}

Species richness, soil cover proportion, and biomass of understory vegetation were not significantly affected by alternative slash management methods. However, the number of species was usually highest when slash was removed, with woody perennials being dominant at the end of the rotation period.

Spreading of residues over treatment plots was usually associated to lower species number and proportion of soil cover, apparently inhibiting the development of woody perennials except when woody debris were concentrated between tree rows.

The incorporation of residues by harrowing apparently induced the dominance of bracken ( $P$. aquilinum) in the understory cover along the rotation, especially in its second half, probably as a consequence of fragmentation of its rhizomes by soil perturbation to incorporate the residues.

Dendrometric parameters indicated that removal of harvesting residues had no significant negative effects on tree growth and timber production during the early rotation stage (Madeira et al. 2004). Results indicate that slash removal does not necessarily have negative effects on production or understory species diversity. However, this statement must take into account site specificity and should be consolidated with further research.

Acknowledgments The experiment was funded by EU (Project CEC AIR-CT-92-0492), JNICT/FCT, Portugal (Projects PDGT/FER/ 366/94 and PRAXIS XXI 3/3.2/FLOR/2123/95) and PAMAF and AGRO Programs (Ministry of Agriculture), Portugal (Projects PAMAF 4029/95 and AGRO 19). Maria do Céu Martins, Cláudia Cerveira, Conceição Santos, and Marta Carneiro were granted, as graduation students and/or junior scientists, by JNICT/FCT. The pulp company Celulose Beira Industrial (CELBI), S. A., landowner of Quinta do Furadouro, supervised the management of the experimental area. Samantha Hughes is gratefully acknowledged for English revision.

\section{References}

Abbott DT, Crossley Jr DA (1982) Woody litter decomposition following clear-cutting. Ecology 63:35-42 
Alves AAM, Pereira JMS, Borges JGC, Borges GC, Carvalho PO, David JS, Gonçalves JHC, Madeira M, Onofre N, Valente F (1990) Impactes Ambientais e Sócio-Económicos do Eucaliptal em Portugal. Departamento de Engenharia Florestal, Universidade Técnica de Lisboa-Instituto Superior de Agronomia, Lisboa

Alves AAM (1988) Técnicas de produção florestal. Fundamentos, tipificação e métodos, 2nd edn. Instituto Nacional de Investigação Científica, Lisboa

Bailey JD, Tappeiner JC (1998) Effects of thinning on structura development in 40- to 100-year-old Douglas-fir stands in western Oregon. Forest Ecol Manag 108:99-113

Barnes BV, Zak DR, Denton SR, Spurr SH (1998) Forest ecology, 4th edn. Wiley, New York

Bauhus J, Aubin I, Messier C, Connell M (2001) Composition, structure, light attenuation and nutrient content of understory vegeation in a Eucalyptus sieberi regrowth stand 6 years after thinning and fertilisation. Forest Ecol Manag 144:275-286

Begon M, Harper JL, Townsend CR (1996) Ecology, 3th edn. Blackwell Science, Oxford

Bengtsson J, Nilsson SG, Franc A, Menozzi P (2000) Biodiversity, disturbances, ecosystem function and management of European forests. Forest Ecol Manag 132:39-50

Bernaldez FG, Perez RP, Levassor C (1989) Effets des Plantations d'Eucalyptus dans le Nord d'Espagne. Commission des Communautés Européennes, Brussels

Brokaw NV, Lent RA (1999) Vertical structure. In: Hunter Jr ML (ed) Maintaining biodiversity in forest ecosystems. Cambridge University Press, Cambridge, pp 373-399

Brosofske KD, Chen J, Crow TR (2001) Understory vegetation and site factors: implications for a managed Wisconsin landscape. Forest Ecol Manag 146:75-87

Burger JA, Prichett WL (1984) Effects of clearfelling and site preparation on nitrogen mineralization in a southern pine stand. Soil Sci Soc Am J 48:1432-1437

Carnus JM, Parrotta J, Brockerhoff EG, Arbez M, Jactel H, Kremer A, Lamb D, O'Hara K, Walters B (2003) Planted forests and biodiversity. In: UNFF Intersessional Experts Meeting on the Role of Planted Forests in Sustainable Forest Management, New Zealand

Fabião A, Martins MC, Cerveira C, Santos C, Lousã M, Madeira M, Correia A (2002) Influence of soil and organic residue management on biomass and biodiversity of understory vegetation in a Eucalyptus globulus Labill. plantation. Forest Ecol Manag 171:87-100

FAO/UNESCO (1988) Soil map of the world (revised legend). FAO, Rome

Hartley MJ (2002) Rationale and methods for conserving biodiversity in plantation forests. Forest Ecol Manag 155:81-95

Humphrey JW, Hawes C, Peace AJ, Ferris-Kaan R, Jukes MR (1999) Relationship between insect diversity and habitat characteristics in plantation forests. Forest Ecol Manag 113:11-21

Keenan R, Lamb D, Woldring O, Irvine T, Jensen R (1997) Restoration of plant biodiversity beneath tropical tree plantations in Northern Australia. Forest Ecol Manag 99:117-131
Kent M, Coker P (1992) Vegetation description and analysis: a practical approach. Belhaven Press, London

Lugo AE (1997) The apparent paradox of reestablishing species richness on degraded lands with tree monocultures. Forest Ecol Manag 99:9-19

Madeira M, Magalhães MC, Azevedo A, Fabião A, Araújo MC, Pina JP (2004) Efeito da gestão dos resíduos de abate nas características do solo e no crescimento de uma plantação de Eucalyptus globulus, em talhadia. Rev Ciências Agrárias 27(1):414-431

Madeira M, Melo G, Alexandre C, Steen E (1989) Effects of deep ploughing and superficial disc harrowing on physical and chemical soil properties and biomass in a new plantation of Eucalyptus globulus. Soil Till Res 14:163-175

Mendham DS, O'Connell AM, Grove TS, Rance SJ (2003) Residue management effects on soil carbon and nutrient contents and growth of second rotation eucalypts. Forest Ecol Managent $181: 357-372$

Moore SE, Allen HL (1999) Plantation forestry. In: Hunter Jr ML (eds) Maintaining biodiversity in forest ecosystems. Cambridge University Press, Cambridge, pp 400-433

Nyland RD, Leaf AL, Bickelhaut DH (1979) Litter removal impairs growth of direct seeded Norway spruce. Forest Sci $25: 244-246$

Oberhauser U (1997) Secondary forest regeneration beneath pine (Pinus kesiya) plantations in the northern Thai highlands: a chronosequence study. Forest Ecol Manag 99:171-183

Reis RM, Gonçalves MZ (1981) Caracterização climática da região agrícola do ribatejo e oeste. O Clima de Portugal. Fasc. XXXII. Instituto Nacional de Meteorologia e Geofísica, Lisboa

Rosa ML, Gomes MF, Espírito-Santo MD (1986) Influência de factores ecológicos e fitotécnicos na Flora espontânea de sistemas florestais da região de Castelo Branco. In: 1st Congresso Florestal Nacional. Fundação Calouste Gulbenkian, Lisboa, pp 255-260

Smith DM, Larson BC, Kelty MJ, Ashton PMS (1997) The practice of silviculture: applied forest ecology, 9th edn. Wiley, New York

Spies T (1997) Forest stand structure, composition and function. In: Kohm KA, Franklin JF (eds) Creating a forestry for the 21st century: the science of ecosystem management. Island Press, Washington DC, pp 11-30

Thomas SC, Halpern CB, Falk DA, Liguori DA, Austin KA (1999) Plant diversity in managed forests: understory responses to thinning and fertilization. Ecol Appl 9(3):864-879

Tisdall JM, Oades JM (1982) Organic matter and water stable aggregates in soils. J Soil Sci 33:141-163

Zbyszewski G, Almeida FM (1960) Carta geológica de Portugal (Esc 1:50 000). Notícia Explicativa da Folha 26-D. Serviços Geológicos de Portugal, Lisboa 